\title{
Pengaruh Model Pembelajaran TTW Berbasis Penilaian Kinerja terhadap Hasil Belajar Menulis Puisi
}

\author{
Gusti Ngurah Arya Surya Wangsa ${ }^{1}$, Ni Ketut Suarni ${ }^{2}$, I Ketut Dibia ${ }^{3}$ \\ 1,3 Jurusan PGSD, 2 Jurusan BK, Fakultas IImu Pendidikan \\ Universitas Pendidikan Ganesha \\ Singaraja, Indonesia \\ e-mail : nguraharya868@gmail.com ${ }^{1}$,niketut.suarni@undiksha.ac.id ${ }^{2}$ \\ iketutdibia@undiksha.ac.id ${ }^{3}$
}

\begin{abstract}
Abstrak
Penelitian ini bertujuan untuk mengetahui pengaruh yang signifikan model pembelajaran Think Talk Write berbasis Penilaian Kinerja terhadap hasil belajar menulis puisi siswa kelas $\mathrm{V}$ SD. Jenis penelitian ini adalah penelitian eksperimen semu yang menggunakan desain nonequivalent posttest only control group design. Sampel dalam penelitian kelas eskperimen adalah SD Negeri 3 Bulian dengan jumlah siswa 27 orang siswa dan 26 orang siswa SD Negeri 2 Bulian dilibatkan sebagai kelompok kontrol. Pengumpulan data pada penelitian ini menggunakan metode unjuk kerja yaitu hasil belajar menulis puisi. Data yang dikumpulkan dianalisis menggunakan analisis statistik deskriptif dan statistik inferensial (uji-t). Hasil penelitian ini menemukan bahwa terdapat pengaruh yang signifikan model pembelajaran Think Talk Write berbasis Penilaian Kinerja terhadap hasil belajar menulis puisi siswa kelas V SD gugus IV Cempaka Putih kecamatan kubutambahan kabupaten buleleng dengan hasil nilai signifikan $0,00<0,05$ maka $H_{1}$ diterima dan $H_{0}$ ditolak. Hal ini berarti bahwa penerapan model pembelajaran Think Talk Write berbasis penilaian berpengaruh signifikan terhadap hasil belajar menulis puisi siswa kelas $\mathrm{V}$.
\end{abstract}

Kata-kata kunci: TTW, Penilaian Kinerja, hasil belajar

\begin{abstract}
The purpose of this study was to figure out the significant effect of Think Talk and Write technique with performance-based assessment towards students' poetry writing achievement in fifth grade of primary schools. This was a quasi-experimental study utilising non-equivalent posttest only control group design. The samples of this study were 27 students from SD Negeri 3 Bulian as experimental group and 26 students from SD N 2 Bulian as control group. The data were obtained through performance-based assessment namely students' poetry writing achievement. The data were analysed descriptively and inferentially (t-test). The result of the study shows that there is a significant effect on the use of Think Talk and Write technique with performance-based assessment towards students' poetry writing achievement in fifth grade of Kubutambahan district cluster IV CempakaPutih primary schools, Buleleng regency in which the result is $0.000<0.05$. It accepts $H_{1}$ and rejects $H_{0}$. This indicates that the implementation of Think Talk and Write technique with performance-based assessment gives a significant effect towards students' poetry writing achievement in fifth grade of primary schools.
\end{abstract}

Keywords: Performance-based Assessment, Students' Poetry Writing Achievement, TTW 


\section{Pendahuluan}

Pendidikan bagi kehidupan umat manusia merupakan kebutuhan mutlak yang harus dipenuhi sepanjang hayat. Semakin tinggi cita-cita manusia semakin menuntut kepada peningkatan mutu pendidikan sebagai sarana untuk mencapai tujuan pendidikan di Indonesia. Tujuan tersebut tertuang dalam Undang-Undang Republik Indonesia Nomor 20 Tahun 2003 tentang Sistem Pendidikan Nasional Pasal 3 yaitu : "Untuk berkembangnya potensi peserta didik agar menjadi manusia yang beriman dan bertakwa kepada Tuhan Yang Maha Esa, berakhlak mulia, sehat, berilmu, cakap, kreatif, mandiri, dan menjadi warga negara yang demokratis serta bertanggung jawab".

Untuk mencapai tujuan dari pendidikan nasional dapat ditempuh melalui pendidikan formal, informal dan non formal. Khususnya Pendidikan formal merupakan pendidikan yang diselenggarakan di sekolah pada umumnya. Dalam hal ini, pendidikan di Indonesia harus mendapat perhatian yang serius dari berbagai faktor, seperti guru, peserta didik, kurikulum, serta sarana dan prasarana pendukung pembelajaran. Ketentuan mengenai pengembangan kurikulum sebagaimana yang tercantum dalam Undang-undang No. 20 tahun 2003 tentang Sistem Pendidikan Nasional, Pasal 37 Ayat 1 menyebutkan bahwa kurikulum pada jenjang pendidikan dasar dan menengah wajib memuat 10 mata pelajaran. Salah satunya ialah bahasa Indonesia. Menurut Badan Standar Nasional Pendidikan (BNSP, 2006: 81) standar isi bahasa Indonesia sebagai berikut, "pembelajaran bahasa Indonesia diarahkan untuk meningkatkan kemampuan peserta didik untuk berkomunikasi dalam bahasa Indonesia dengan baik dan benar, baik secara lisan maupun tulis, serta menumbuhkan apresiasi terhadap hasil karya kesastraan manusia Indonesia". Standar kompetensi mata pelajaran bahasa Indonesia berorientasi pada hakikat pengajaran bahasa, bahwa belajar bahasa adalah belajar komunikasi. Oleh karena itu, pengajaran bahasa Indonesia diarahkan untuk membina kemampuan siswa yaitu berkomunikasi dalam bahasa Indonesia, baik secara lisan maupun tertulis.

Hal ini sejalan dengan pendapat Susanto (2013:241) yang menyatakan bahwa salah satu keterampilan yang diharapkan dimiliki oleh siswa dari sekolah dasar adalah keterampilan berbahasa yang baik, karena bahasa merupakan modal terpenting bagi manusia. Dalam pengajaran bahasa Indonesia ada empat keterampilan berbahasa yang harus dimiliki oleh siswa. Keterampilan ini, antara lain mendengarkan, berbicara, membaca dan menulis. Keempat aspek berbahasa ini saling terkait antara satu dengan yang lainnya. Bagaimana seorang anak akan bisa menceritakan sesuatu setelah ia membaca ataupun setelah ia mendengarkan. Begitu pun dengan menulis. Menulis tidak lepas dari kemampuan menyimak, membaca dan berbicara anak sehingga keempat aspek ini harus senantiasa diperhatikan untuk meningkatkan kemampuan siswa.

Untuk mencapai tujuan tersebut pembelajaran bahasa Indonesia di SD harus sesuai dengan karakteristik siswa yang masih berada pada tahap oprasional konkret, yang belum bisa berpikir abstrak dan memiliki karakteristik yang beragam. Pembelajaran bahasa Indonesia di SD hendaknya dirancang agar sesuai dengan kebutuhan siswanya yang sesuai dengan karakteristik siswa SD. Dengan demikian kualitas hasil belajar bahasa Indonesia akan meningkat, namun kenyataannya belum mencapai hasil belajar yang diharapkan.

Berdasarkan hasil wawancara, observasi dan studi dokumen yang dilakukan pada tanggal 22 November 2017 dengan guru kelas V di SD Negeri Gugus IV Cempaka Putih kecamatan Kubutambahan, hasil wawancara yang diperoleh yaitu dalam proses pembelajaran bahasa Indonesia khususnya dalam menulis puisi masih banyak siswa yang kurang aktif dalam mengikuti pembelajaran, sulit untuk menuangkan ide, kosa kata dan kurang termotivasi siswa dalam mengikuti pembelajaran dikelas. Dilanjutkan dengan observasi pada saat guru melaksanakan pembelajaranbahasa Indonesia di kelas mendapatkan hasil yaitu : (1) Pembelajaran yang dilaksanakan di kelas masih menggunakan pembelajaran yang berpusat pada guru dan jarangnya penggunaaan model pembelajaran. (2) Dalam pelaksanaan pembelajaran terutama mata pelajaran bahasa Indonesia, penggunaan media pembelajaran yang diterapkan oleh guru kurang bervariasi sehingga membuat siswa merasa bosan. Hal tersebut akan berpengaruh terhadap hasil belajar menulis puisi yang diperoleh siswa menjadi kurang baik.

Berdasarkan hasil studi dokumen, tentang nilai keterampilan menulis siswa kelas V SD Gugus IV Cempaka Putih kecamatan Kubutambahan Kabupaten Buleleng tahun pelajaran 2017/2018 terdapat pada Tabel 1. 
Tabel 1. Nilai Rata-Rata Keterampilan Menulis Puisi Siswa Kelas V SD

\begin{tabular}{lccc}
\hline \multicolumn{1}{c}{ Sekolah } & KKM & $\begin{array}{c}\text { Nilai Rata-rata } \\
\text { Kelas }\end{array}$ & Jumlah siswa \\
\hline SD Negeri 2 Bulian & 65 & 63,32 & 26 \\
SD Negeri 3 Bulian & 68 & 65 & 27 \\
SD Negeri 1 Depeha & 63 & 57 & 31 \\
SD Negeri 2 Depeha & 65 & 63,06 & 33 \\
SD Negeri 3 Depeha & 67 & 66,76 & 25 \\
SD Negeri 4 Depeha & 70 & 66,22 & 27 \\
\hline
\end{tabular}

(Sumber: Arsip nilai Bahasa Indonesia di Gugus IV Cempaka Putih)

Berdasarkan Tabel 1 di atas, maka dapat diketahui bahwa nilai rata-rata siswa yang ada di SD Gugus IV Cempaka Putih Kecamatan Kubutambahan berkisar antara 57- 66,76 jika dikonversikan dengan kriteria penilaian acuan patokan (PAP) menurut Agung (2014:118) berada pada kategori rendah. Hal ini merupakan suatu masalah yang harus di atasi agar hasil belajar menulis puisi siswa menjadi lebih baik.

Solusi yang tepat untuk mengatasi masalah diatas perlu diterapkannya berbagai jenis pendekatan, strategi dan model pembelajaran. Salah satu model pembelajaran yang dapat digunakan untuk mengatasi permasalahan diatas adalah model pembelajaran Think Talk Write (TTW). Model pembelajaran ini mempunyai keunggulan membangun pengetahuan awal siswa, mulai siswa itu berfikir, berbicara dan menulis yang nantinya akan menghasilkan sebuah produk karya sastra berupa puisi. Selain itu, akan lebih menarik lagi jika pembelajaran ini dilakukan di luar lingkungan kelas. Menurut Ngalimun dkk (2015:238) Think Talk Write (TTW) adalah "pembelajaran yang dimulai dengan berpikir melalui bahan bacaan (menyimak, mengkritisi, dan alternative solusi), hasil bacaanya dikomunikasikan dengan presentasi, diskusi dan kemudian buat laporan dari persentasi". Menurut Setiyaningrum (2015) Model pembelajaran kooperatif tipe Think-Talk-Write (TTW) merupakan suatu model pembelajaran yang dibangun melalui tiga hal yaitu berpikir, berbicara, dan menulis. Alur pembelajaran model Think-Talk-Write (TTW) dimulai dari keterlibatan siswa dalam berpikir dan berdialog dengan dirinya sendiri setelah proses membaca, selanjutnya berbicara dan membagi ide (sharing) dengan temannya sebelum menulis. Menurut Riski (2017) Model pembelajaran ini membuat siswa lebih berperan aktif dan berperan lebih dominan dibanding guru. Tugas guru dalam model pembelajaran TTW hanya sebagai fasilitator dan motivator dalam pembelajaran. Namun, guru sebagai fasilitator harus selalu memantau perkembangan aktivitas siswa dan mendorong siswa agar mencapai tujuan yang hendak dicapai. Menurut Hamdayama (2014:217) Think Talk Write adalah sebuah pembelajaran yang dimulai dengan berpikir melalui bahan bacaan (menyimak, mengkritisi, dan alternatif solusi), hasil bacaannya dikomunikasikan dengan presentasi, diskusi, dan kemudian membuat laporan hasil presentasi. Dalam proses pembelajaran siswa membaca suatu bacaan lalu berpikir dan membuat catatan kecil, dan kemudian menjelaskan kepada kelompoknya, sehingga setiap anggota kelompok saling menuangkan ide masing-masing, dan kemudian menuangkan hasil diskusi melalui tulisan. Sedangkan menurut Iru dan Arihi (2012:68) model pembelajaran Think Talk Write merupakan model pembelajaran dimana perencanaan dari tindakan yang cermat mengenai kegiatan pembelajaran yaitu melalui berpikir, bertukar pendapat, dan menuliskan hasil diskusi agar tujuan pembelajaran dapat tercapai. Menurut Hartanto (2017) model pembelajaran Think Talk Write menggunakan kelompokkelompok kecil dan menuntut siswa untuk bekerjasama, berdiskusi, berbagi ilmu pengetahuan, saling berkomunikasi, dan saling membantu untuk memahami materi pelajaran. Dalam model ini, siswa dituntut untuk melakukan tiga aktifitas, yaitu berpikir (think), berbicara (talk), dan menulis (write).

Penilaian Kinerja (performance assessment) adalah suatu penilaian alternative berdasarkan tugas jawaban terbuka (open ended task) atau hands-on yang dirancang untuk mengukur kriteria siswa terhadap seperangkat kriteria tertentu. Penilaian kinerja mensyaratkan siswa dalam menyelesaikan tugas-tugas kenerjanya menggunakan pengetahuan dan keterampilannya yang diwujudkan dalam bentuk perbuatan, tindakan atau unjuk kerja.

Jika model pembelajaran TTW berbasis penilaian kinerja dilakukan dengan baik maka pelaksanaan pembelajaran tersebut akan lebih efektif sesuai dengan sintak pembelajarannya, karena melalui penilaian kinerja mensyaratkan siswa dalam menyelesaikan tugas-tugas kinerjanya menggunakan keterampilan dalam bentuk perbuatan. Hal ini dapat dinyatakan 
bahwa model pembelajaran TTW sangat efektif diterapkan dalam proses pembelajaran karena dilihat dari penelitian yang dilakukan oleh Sugiarti (2014) penerapan model pembelajaran TTW (Think Talk Write) berbantuan media gambar berseri terhadap keterampilan menulis menunjukkan hasil, nilai rata-rata siswa lebih besar dari nilai rata-rata siswa yang dibelajarkan secara konvensional.

Berdasarkan latar belakang tersebut, penerapan model pembelajaran Think Talk Write (TTW) berbasis Penilaian Kinerja diharapkan dapat meningkatkan hasil belajar menulis puisi siswa kelas V. Untuk itu perlu dilaksanakan penelitian dengan judul "PengaruhModel PembelajaranThink Talk Write (TTW) Berbasis Penilaian Kinerja Terhadap Hasil Belajar Menulis Puisi Siswa Kelas V SD Negeri di Gugus IV Cempaka Putih Kecamatan Kubutambahan, Kabupaten Buleleng Tahun Pelajaran 2017/2018.

\section{Metode}

Jenis penelitian yang dilakukan adalah penelitian eksperimen. Menurut pendapat Koyan (2012) menyatakan penelitian ini merupakan penelitian eksperimen semu (quasi eksperiment), mengingat tidak semua variabel (gejala yang muncul) dan kondisi eksperimen dapat diatur dan dikontrol secara ketat. Pada dasarnya penelitian ini bertujuan untuk menganalisis perbedaan hasil belajar antara siswa yang mengikuti pembelajaran dengan model pembelajaran Think Talk Write (TTW) berbasis penilaian kinerja dengan siswa yang tidak mengikuti model pembelajaran TTW berbasis penilaian kinerja.

Penelitian ini menggunakan desain eksperimen non equivalen post-test only control group design. Secara prosedural desain penelitian ini disajikan dalam Tabel 2 berikut.

Tabel 2. Desain Penelitian"Post-test Only Control Group Design"

\begin{tabular}{lll}
\hline Kelas & Treatment & Post-test \\
\hline Eksperimen & $\mathrm{X}$ & $\mathrm{O}_{1}$ \\
Kontrol & - & $\mathrm{O}_{2}$ \\
\hline
\end{tabular}

(Sumber: Sugiyono,2010)

Keterangan :

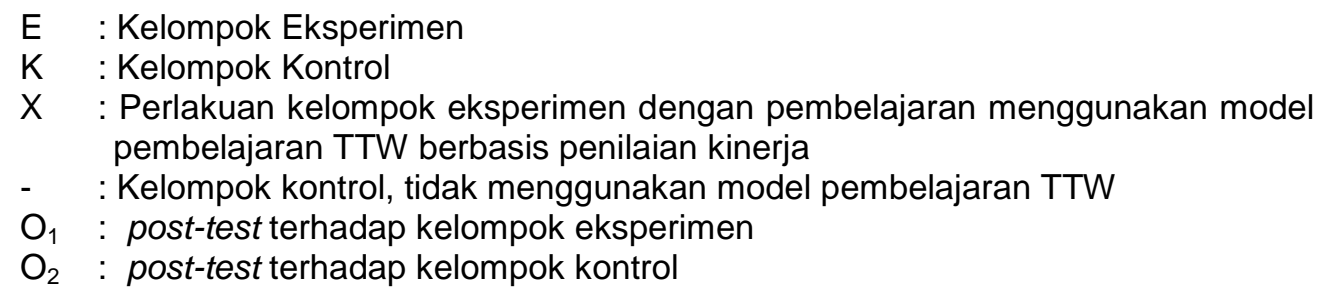

Berdasarkan Tabel 2 di atas kelompok pertama (kelompok eksperimen) diberikan perlakuan mengenai model pembelajaran Think Talk Write (TTW) berbasis Penilaian Kinerja sedangkan kelompok kedua (kelompok kontrol) tidak mendapat perlakuan dengan menggunakan model pembelajaran TTW berbasis penilaian kinerja. Adapun tempat pelaksanaan penelitian ini adalah di SD Gugus IV Cempaka Putih, Kecamatan Kubutambahan, Kabupaten Buleleng Tahun Pelajaran 2017/2018. Penelitian ini dilaksanakan pada semester II (genap) tahun pelajaran 2017/2018.

Adapun tempat pelaksanaan penelitian ini adalah SD Gugus IV Cempaka Putih Kecamatan Kubutambahan Kabupaten Buleleng Tahun Pelajaran 2017/2018. Penelitian ini dilaksanakan pada semester II (genap) tahun pelajaran 2017/2018.

Populasi sangat diperlukan di dalam penelitian karena merupakan subjek dalam penelitian. Agung (2014:69) menyatakan populasi adalah keseluruhan objek dalam suatu penelitian.Populasi dalam penelitian ini adalah seluruh siswa kelas V SD Gugus IV Cempaka Putih Kecamatan Kubutambahan, Kabupatan Buleleng. Banyak siswa seluruhnya adalah 169 orang yang tersebar dalam 6 SD Negeri.

Setelah semua kelas dinyatakan setara, maka dilanjutkan dengan penentuan sampel penelitian. Penentuan sampel menggunakan teknik random sampling. Semua nama sekolah di Gugus IV Cempaka Putih, Kecamatan Kubutambahan, Kabupaten Buleleng ditulis dalam kertas kecil, kemudian digulung, selanjutnya dipilih dua gulungan kertas secara acak. Hasilnya adalah SD Negeri 2 dan SD Negeri 3 Bulian sebagai sampel penelitian. Seluruh kelas V SD Negeri 2 
Bulian yang berjumlah 26 siswa sebagai kelas eksperimen dan seluruh siswa kelas V SD Negeri 3 Bulian yang berjumlah 27 siswa sebagai kelas kontrol.

Dalam penelitian ini, metode pengumpulan data yang digunakan adalah metode unjuk kerja. Dari pemaparan di atas, dapat disimpulkan dalam bentuk tabel. Simpulan metode dan instrumen pengumpulan data dapat disajikan dalam Tabel 3.

Tabel 3. Metode dan Instrumen Pengumpulan Data

\begin{tabular}{lllll}
\hline Variabel & Metode & Instrumen & Sumber Data & Sifat Data \\
\hline $\begin{array}{l}\text { Hasil belajar } \\
\text { menulis puisi }\end{array}$ & Unjuk kerja & $\begin{array}{l}\text { Rubrik penilaian } \\
\text { menulis puisi }\end{array}$ & Puisi & $\begin{array}{l}\text { Skor } \\
\text { (interval) }\end{array}$ \\
\hline
\end{tabular}

\section{Hasil dan Pembahasan}

Data yang dikumpulkan dalam penelitian ini yaitu data tentang hasil belajar menulis puisi pada kelompok siswa yang dibelajarkan menggunakan model pembelajaran Think Talk Wrire berbasis Penilaian Kinerja maupun kelompok siswa yang dibelajarkan tanpa menggunakan model pembelajaran Think Talk Wrire berbasis Penilaian Kinerja. Posttest dilakukan dengan memberikan kertas gambar meminta siswa untuk memilih salah satu gambar kemudian menulis puisi sesuai dengan gambar yang dipilih. Jumlah siswa yang dianalisis data hasil belajar menulis puisi pada kelompok eksperimen adalah 27 orang siswa dan pada kelompok kontrol berjumlah 26 orang siswa.

Deskripsi hasil penelitian data hasil belajar menulis puisi siswa memaparkan mean, median, modus, varians dan standar deviasi. Hasil deskripsi data dapat dilihat pada Tabel 4.

Tabel 4. Deskripsi Data Hasil Belajar Menulis Puisi

Hasil Analisis

\begin{tabular}{lcc}
\hline Mean & 16,81 & 13,35 \\
Median & 17,38 & 13,27 \\
Modus & 18,3 & 13,5 \\
Varians & 8,52 & 1,87 \\
Standar Deviasi & 2,92 & 1,37 \\
\hline
\end{tabular}

Berdasarkan Tabel 4, nilai rata-rata hasil belajar menulis puisi kelompok siswa yang dibelajarkan menggunakan model pembelajaran Think Talk Wrire berbasis Penilaian Kinerja sebesar $=16,81$ dengan varians $=8,52$ dan standar deviasi $=2,92$. Sedangkan nilai rata-rata hasil belajar menulis puisi kelompok siswa yang dibelajarkan tanpa menggunakan model pembelajaran Think Talk Wrire berbasis Penilaian Kinerja sebesar $=13,35$ dengan varians $=$ 1,87 dan standar deviasi $=1,37$.

Dari data tersebut, menunjukkan bahwa kelompok siswa yang dibelajarkan menggunakan model pembelajaran Think Talk Wrire berbasis Penilaian Kinerja memiliki nilai rata-rata hasil belajar yang lebih tinggi dibandingkan kelompok siswa yang dibelajarkan tanpa menggunakan model pembelajaran Think Talk Wrire berbasis Penilaian Kinerja.

Untuk memperoleh gambaran tentang hasil belajar menulis puisi kelompok eksperimen dapat dideskripsikan mean (M), median (Md), Modus (Mo), varians, dan standar deviasi (s) dari data hasil post-test kelompok control, yaitu: mean $(\mathrm{M})=16,81$, median $(\mathrm{Md})=17,38$, Modus $(\mathrm{Mo})=18,3$ varians $\left(\mathrm{s}^{2}\right)=8,54$, dan standar deviasi $(\mathrm{s})=2,92$. Kemudian data hasil belajar menulis puisi dapat disajikan ke dalam bentuk grafik batang sebagai berikut. 
Titik Tengah

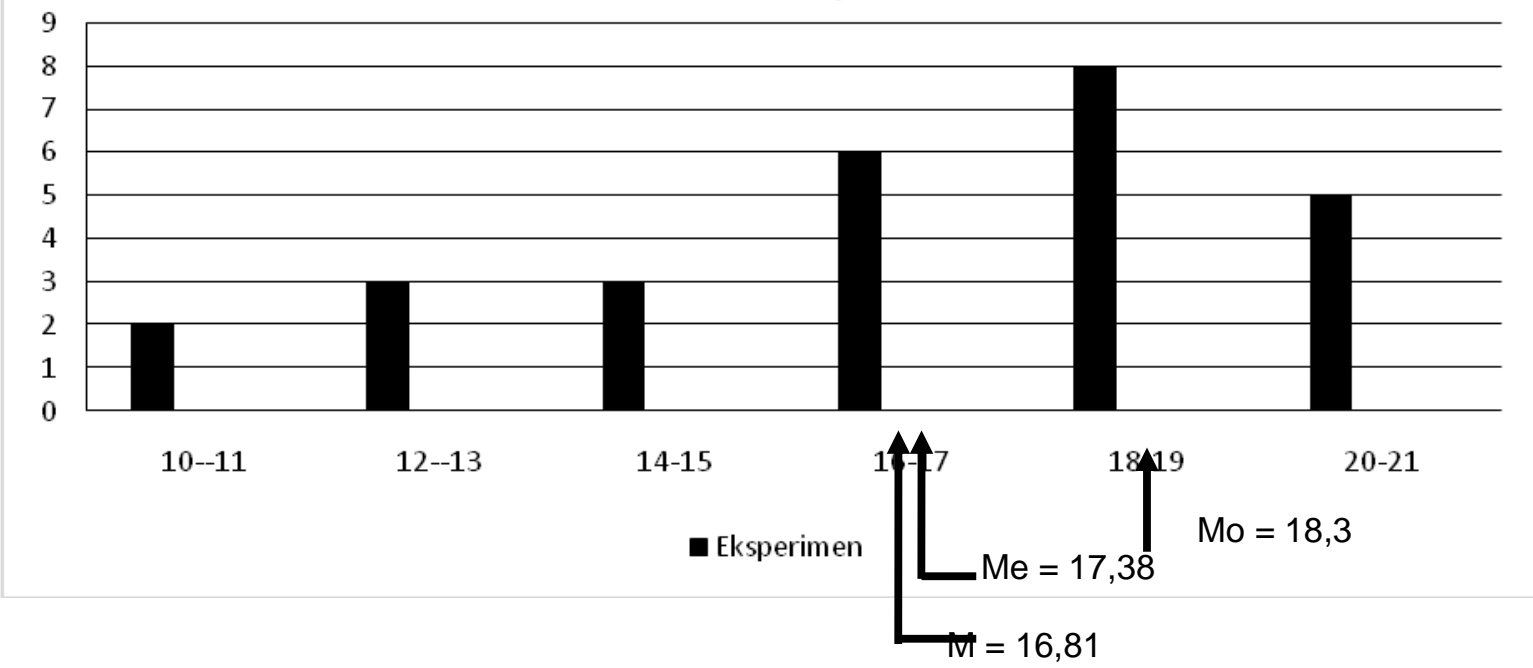

Gambar 1. Grafik Hasil Belajar Kelompok Eksperimen

Gambar 1 menunjukkan bahwa harga statistik Mo>Me>M dan tergolong diagram batangnegative . Berdasarkan gambar tersebut dapat diinterpretasikan bahwa rata-rata skor hasil belajar menulis puisi siswa cenderung tinggi.

Sedangkan data hasil belajar menulis puisi diketahui mean (M), median (Md), Modus (Mo), varians, dan standar deviasi (s) dari data hasil post-test kelompok control, yaitu: mean $(M)=13,27$ median $(\mathrm{Md})=13,5$, Modus $(\mathrm{Mo})=13,35$ varians $\left(\mathrm{s}^{2}\right)=9,08$, dan standar deviasi $(\mathrm{s})$ $=3,01$.

\section{Titik Tengah}

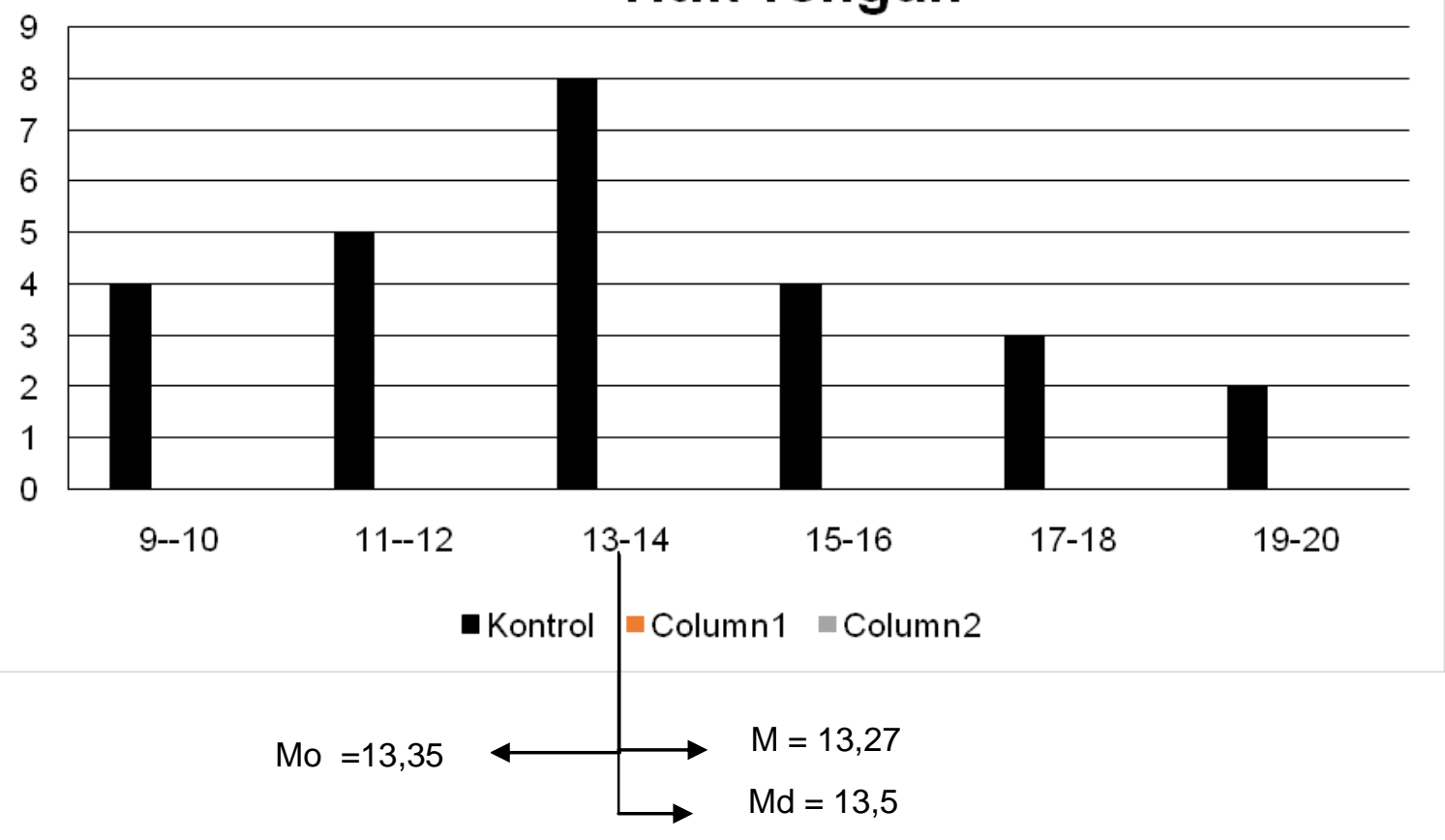

Gambar 2. Grafik Hasil Belajar Kelompok Kontrol 
Berdasarkan hasil perhitungan tersebut, diketahui mean selanjutnya dilakukan menyusun tabel konversi untuk menentukan kategori skor hasil belajar menulis puisi terlebih dahulu dengan mean ideal (Mi) dan standar deviasi ideal (SDi).

Kemudian dilakukan uji hipotesis untuk mengetahui pengaruh dari model pembelajaran yang ditetapkan. Namun sebelum dilakukan uji hipotesis terlebih dahulu dilakukan uji prasyarat analisis data yaitu normalitas dan homogenitas. Berdasarkan hasil uji prasyarat analisis diperoleh bahwa hasil belajar menulis puisi siswa kelompok eksperimen dan kontrol adalah normal dan varians kedua kelompok adalah homogen. Untuk itu hipotesis dilakukan dengan menggunakan uji-t disajikan pada Tabel 5.

Tabel 5. Independent Samples Test

\section{t-test for Equality of Means}

\begin{tabular}{|c|c|c|c|c|c|c|c|c|c|}
\hline & & $\begin{array}{l}\text { Leven } \\
\text { for Eq } \\
\text { Vari }\end{array}$ & $\begin{array}{l}\text { s Test } \\
\text { lity of } \\
\text { ices }\end{array}$ & & & & & & $\begin{array}{c}95 \% \\
\text { Confidence } \\
\text { Interval of } \\
\text { the } \\
\text { Difference }\end{array}$ \\
\hline & & $\mathbf{F}$ & Sig. & $\mathbf{t}$ & Df & $\begin{array}{c}\text { Sig. } \\
(2- \\
\text { tailed } \\
)\end{array}$ & $\begin{array}{c}\text { Mean } \\
\text { Differe } \\
\text { nce }\end{array}$ & $\begin{array}{c}\text { Std. } \\
\text { Error } \\
\text { Diere } \\
\text { nce } \\
\end{array}$ & Lower Upper \\
\hline sil & $\begin{array}{l}\text { Equal variances } \\
\text { assumed }\end{array}$ & .004 & .951 & 4.348 & 51 & .000 & 3.54558 & .81545 & $\begin{array}{cc}1.9084 & 5.1826 \\
9 & 7\end{array}$ \\
\hline lajar & $\begin{array}{l}\text { Equal variances } \\
\text { not assumed }\end{array}$ & & & 4.345 & $\begin{array}{c}50.7 \\
56\end{array}$ & .000 & 3.54558 & .81594 & $\begin{array}{cc}1.9073 & 5.1838 \\
3 & 4\end{array}$ \\
\hline
\end{tabular}

Berdasarkan hasil analisis di atas, dapat dilihat bahwa besar signifikan (2-tailed) sebesar 0,000 . Hasil menunjukan besar signifikan lebih kecil dari $0,05 \quad(p>0,05)$, sehingga hasilnya adalah signifikan maka $\mathrm{H}_{1}$ diterima dan $\mathrm{H}_{0}$ ditolak, ini berarti terdapat pengaruh yang signifikan model pembelajaran Think Talk Write berbasis penilaian kinerja terhadap hasil belajar menulis puisi pada siswa kelas V SDN di Gugus IV Cempaka Putih, Kecamatan Kubutambahan, Kabupaten Buleleng.

Penggunaan model pembelajaran TTW berbasis penilaian kinerja memiliki efektivitas yang tinggi terhadap hasil belajar menulis. Maksudnya adalah selama proses pembelajaran berlangsung siswa lebih mudah dalam menuangkan ide, gagasan, berimajinasi dan memilih kosa kata yang tepat saat menulis puisi dikarenakan pembelajaran yang diberikan oleh guru tidak monoton dilakukan di dalam kelas. Siswa dihadapkan langsung dengan lingkungan sehingga siswa lebih mudah dalam menuangkan ide yang dimiliki, siswa lebih aktif dalam berinteraksi dan diskusi untuk menyampaikan gagasan yang mereka miliki dan siswa merasa lebih senang dalam mengikuti proses pembelajaran yang dilakukan. Penelitian ini sejalan dengan hasil penelitian yang dilakukan oleh Dewi (2016) model TTW dapat menciptakan suasana belajar yang menyenangkan selanjutnya penelitian yang dilakukan Juniardi (2017) dengan model pembelajaran TTW, siswa diajak berpikir secara langsung menemukan konsepkonsep pembelajaran dan berinteraksi dengan temannya, sehingga siswa lebih aktif dan mudah dalam memahami konsep yang diberikan. Apabila siswa aktif dan paham terhadap materi atau konsep pembelajaran, hasil belajar siswa pun dapat meningkat.

Penggunaan model pembelajaran TTW berbasis penilaian kinerja memberikan perubahan kepada siswa dalam hasil belajar khususnya menulis puisi maupun sikap pada diri siswa. Perubahan yang terjadi adalah dengan model pembelajaran TTW siswa termotivasi untuk melakukan proses pembelajaran dan mencapai tujuan pembelajaran yang diinginkan. Model pembelajaran TTWmemotivasi siswa untuk berlatih berpikir, berbicara dan menulis secara kreatif. Pada proses pembelajaran siswa terlihat termotivasi disebabkan karena pada model TTW diterapkan metode diskusi, dalam kegiatan diskusi siswa dibagi dalam kelompokkelompok kecil yang membuat siswa menjadi lebih aktif dalam berinteraksi dan bertukar pikiran. Interaksi yang terjadi antar siswa di dalam kelas menyebabkan siswa menjadi tertarik dan termotivasi dalam mengikuti proses pembelajaran yang akan berdampak pada pencapaian hasil belajar yang lebih baik. Penelitian ini sejalan dengan penelitian yang dilakukan oleh 
Penggunaan model pembelajaran TTW berbasis penilaian kinerja pada hakikatnya memberikan dampak positif kepada siswa karena dalam pengimplementasian Penilaian Kinerja digunakan untuk membantu guru untuk memperoleh informasi tentang apa dan sejauhmana yang telah dilakukan oleh siswa dalam proses pembelajaran. Pemantauan didasarkan pada kinerja yang ditunjukkan dalam menyelesaikan suatu tugas atau permasalahan yang diberikanHasil yang diperoleh merupakan suatu hasil dari unjuk kerja menulis puisi.

Model pembelajaran TTW berbasis penilaian kinerja dapat memberikan pengaruh yang signifikan terhadap hasil belajar menulis puisi bagi siswa.Penggunaan dalam model pembelajaran ini menuntut siswa agar lebih aktif dalam membangun pemahamannya secara mandiri, sehingga akan berdampak sangat positif terhadap hasil belajar siswa. Model pembelajaran ini menekankan proses pembelajaran yang berpusat kepada siswa. Menghindari cara belajar yang berpusat pada guru yang menyebabkan proses pembelajaran pasif sehingga tidak dapat memberikan kesempatan kepada siswa untuk mengakomodasi dan mengonstruksi informasi serta menungkan ide-ide yang dimiliki. Model pembelajaran TTW berbasis nilai penilaian kinerjasebagai bantuan dalam belajar, sehingga proses pembelajaran siswa menjadi lebih bermakna yang tercermin dari penguasaan konsep atau bahan ajar yang mereka pelajari. Dengan kata lain, hal tersebut berimplikasi pada hasil belajar siswa. Penelitian ini diperkuat dengan penelitian yang dilakukan oleh Darmawan (2017) Peningkatan hasil dan aktivitas keterampilan menulis puisi siswa dikarenakan model pembelajaran think talk write yang diterapkan dapat mengubah situasi belajar yang tadinya masih berpusat pada guru menjadi pembelajaran yang tidak hanya berpusat pada guru saja melainkan juga berpusat pada siswa. Siswa dapat lebih leluasa untuk belajar dengan memikirkan permasalahan yang dibahas secara mandiri terlebih dahulu kemudian mendiskusikan pemikiran dengan kelompok dan akhirnya dituangkan ke dalam bentuk tulisan.

Berdasarkan pemaparan diatas, dapat dinyatakan bahwa penggunaan model Think Talk write berbasis penilaian kinerja dalam pembelajaran menulis puisi berpengaruh terhadap hasil belajar siswa kelas $\mathrm{V}$ di gugus IV Cempaka Putih Kecamatan Kubutambahan Kabupaten Buleleng Tahun Pelajaran 2017/2018. Hasil belajar menulis puisi pada kelompok siswa yang dibelajarkan dengan model pembelajaran Think Talk write berbasis penilaian kinerja lebih baik daripada kelompok siswa yang tidak dibelajarkan dengan model Think Talk write berbasis penilaian kinerja.

\section{Simpulan dan Saran}

Berdasarkan hasil pengujian hipotesis dan pembahasan, maka temuan dalam penelitian ini menyatakan bahwa terdapat pengaruh yang signifikan model pembelajaran Think Talk Write (TTW) berbasis Penilaian Kinerja terhadap hasil belajar menulis puisi siswa. hasil analisis di atas, dapat dilihat bahwa besar signifikan (2-tailed) sebesar 0,000. Hasil menunjukan besar signifikan lebih kecil dari 0,05 ( $p>0,05)$, sehingga hasilnya adalah signifikan maka $\mathrm{H}_{1}$ diterima dan $\mathrm{H}_{0}$ ditolak, ini berarti terdapat pengaruh yang signifikan model pembelajaran Think Talk Write berbasis penilaian kinerja terhadap hasil belajar menulis puisi pada siswa kelas V SDN di Gugus IV Cempaka Putih, Kecamatan Kubutambahan, Kabupaten Buleleng. Kualifikasi hasil belajar bahasa Indonesia khususnya dalam menulis puisi siswa yang mengikuti model pembelajaran Think Talk Write berbasis nilai Penilaia Kinerja berada pada kategori sangat baik sedangkan hasil belajar bahasa Indonesia menulis puisi siswa yang tidak diberikan perlakuan model pembelajaran Think Talk Write berbasis Penilaian Kinerja berada pada kategori baik. Skor rata-rata hasil belajarmenulis puisi siswa yang mengikuti model pembelajaran Think Talk Write berbasis Penilaian Kinerja adalah 17,81 sedangkan skor rata-rata hasil belajar siswa yang tidak mendapat perlakuan model pembelajaran pembelajaran Think Talk Write berbasis Penilaian Kinerja adalah 13,26. Berdasarkan temuan tersebut, dapat disimpulkan bahwa pembelajaran dengan model pembelajaran Think Talk Write berbasis Penilaian Kinerja berpengaruh signifikan terhadap hasil belajar menulis puisi siswa kelas V SD di Gugus IV Cempaka Putih Kecamatan Kubutambahan Kabupaten Buleleng tahun pelajaran 2017/2018.

Saran yang dapat disampaikan berdasarkan penelitian yang telah dilakukan adalah sebagai berikut: Disarankan kepada siswa dalam mengikuti proses pembelajaran hendaknya selalu terlibat secara aktif agar nantinya dapat meningkatkan hasil belajar dan mendapatkan pengetahuan baru melalui pengalaman yang ditemukannya sendiri, Disarankan kepada guru dalam menyampaikan materi pelajaran di kelas hendaknya lebih berinovasi dalam memilih model pembelajaran yang mana model pembelajaran yang dipilih nantinya mampu mengatasi kebutuhan belajar dan karakteristik siswa, Disarankan kepada kepala sekolah, khususnya SD 
hendaknya dapat menjadikan model pembelajaran Think Talk Write (TTW) berbasis Penilaian Kinerja menjadi salah satu model pembelajaran yang harus diterapkan dalam pembelajaran, pada aturan guru mengajar dikelas, Disarankan kepada peneliti lain yang akan mengadakan penelitian lebih lanjut tentang pembelajaran Think Talk Write (TTW) berbasis Penilaian Kinerja dalam bidang pelajaranbahasa Indonesia maupun pelajaran lainnya yang sesuai agar memerhatikan kendala-kendala yang dialami dalam penelitian ini sebagai bahan pertimbangan untuk perbaikan dan penyempurnaan penelitian yang akan dilaksanakan.

\section{Daftar Pustaka}

Agung, A. A. (2014). Metodologi Penelitian Pendidikan. Yogyakarta: Aditya Media publishing.

Darmawan Km. Agus. 2017. "Pengaruh Model Pembelajaran Think Talk Writre Berbantuan Media Lingkungan Terhadap Keterampilan Menulis Deskripsi Siswa Kelas V".E-Journal PGSD Universitas Pendidikan Ganesha, Volume 5, Nomor 2.

Hamdayama, Jumanta. 2014. Model Dan Metode Pembelajaran Kreatif Dan Berkarakter. Bogor: Ghalia Indonesia.

Hartanto. 2017. Penerapan Model Pembelajaran Think Talk Write (TTW) dengan Bantuan Lembar Kerja Siswa untuk Meningkatkan Aktivitas dan Hasil Belajar IPA Terpadu Siswa Kelas VII A SMP Negeri 2 Rantau Panjang. Jurnal Inovasi Dan Pembelajaran Fisika Vol. 4 No. 1 Hal. 10-17. http://fkip.unsri.ac.id/index.php/menu/104.

Iru, La dan Arihi L.S. 2012. Analisis Penerapan Pendekatan, Metode, Strategi, dan Modelmodel Pembelajaran. Jogjakarta : Multi Presindo.

Juniardi, Muhammad Alfan. (2017) "Pengaruh Model Pembelajaran TTW Berbantuan Media Video Terhadap Hasil Belajar IPA Kelas V SD". E-Journal PGSD Universitas Pendidikan Ganesha, Volume 5, Nomor 2.

Riski, Riska, Muh. Rizal, Linawati. 2017. Penerapan Model Pembelajaran Kooperatif Tipe Think Talk Write (TTW) untuk Meningkatkan Hasil Belajar Siswa pada Materi Hubungan Sudut Pusat, Panjang Busur, dan Luas Juring di Kelas VIII C SMP Negeri 9 Palu. Jurnal elektronik Pendidikan Matematika Tadulako, Volume 5 Nomor 2, Hal. 175-190. Tersedia Pada: http://jurnal.untad.ac.id/jurnal/index.php/JEPMT/article/view/9097.

Setiyaningrum, Erin, dan Istiqomah. 2015. Efektivitas Penerapan Model Pembelajaran Think Talk - Write terhadap Prestasi Belajar Matematika Siswa Kelas VII SMP Negeri 3 Magelang. UNION: Jurnal Pendidikan Matematika Vol 3 No 1 Hal. 9-16. Tersedia Pada: http://jurnal.ustjogja.ac.id/index.php/union/article/view/270.

Sugiarti, Y. 2014. Pengaruh Model Pembelajaran TTW Berbantuan Media Gambar Berseri Terhadap Keterampilan Menulis Bahasa Indonesia Siswa Kelas V Di Gugus I Kec. Kediri Tahun Pelajaran 2013/2014. E-Journal PGSD Universitas Pendidikan Ganesha, volume: 2, No: 1 tahun 2014

Susanto, A. (2013). Teori Belajar \& Pembelajaran di Sekolah Dasar. Jakarta: Kencana. 